\title{
Х. Клінтон або Д. Трамп: вибір американських політиків українськими школярами в залежності від типу особистості школярів
}

\author{
Катаєв С.Л., Класичний приватний університет
}

В статті аналізуються матеріали соціологічного дослідження, що відбулось у листопаді 2016 р., присвяченого виявленню думки українських школярів щодо бажаного президента Америки серед основних претендентів на цю посаду Д. Тампа та Х. Клінтон. Констатується, що на цю думку вплинули засоби масової інформації та загальні настрої населення України. Стверджується, що електоральні переваги школярів залежать також від їх типів особистості. Це стосується не тільки ситуацій у своїй країні, а й ситуацій, коли електоральні судження стосуються інших країн. Дослідження показує наявність у школярів інтересу до політичних подій у світі, якщо це ширко обговорюється у засобах масових інформації, у суспільстві та має загальне значення для світових процесів. Однією з таких подій були вибори президента в Америці. Школярі обізнані про кандидатів у президенти Америки та мають свою думку щодо того, кому краще бути президентом. Більшість школярів надали перевагу Х. Клінтон, що відповідає загальній суспільній думці українського населення. Якщо зважати на структуру цінностей, то прихильники Клінтон або Трампа серед українських школярів відрізняються за своїм типом особистості. Аналіз ціннісних преференцій респондентів дозволяє зробити висновок, що у більшій мірі прихильники Клінтон належать до постмодерного типу особистості, а прихильники Трампа відносяться до модерного типу особистості. Цей висновок базується на тому, що прихильники Трампа, більше ніж прихильники Клінтон, цінують багатство, бізнес, розваги, а прихильники Клінтон, більше ніж прихильники Трампа, цінують можливості самореалізації, розвиток своїх здібностей, творчу роботу.

Ключові слова: вибори президента; Сполучені Штати Америки; українські підлітки; інтерес до політики; електоральні переваги; соціологічні дослідження; ціннісні орієнтації

\section{H. Clinton or D. Trump: the Choice of American Politicians by the Ukrainian Schoolchildren Depending on the Schoolchildren's Type of Personality}

\section{Kataiev S.L., Classic Private University}

The article analyzes the materials of sociological research that was carried out in November 2016 addressed to find out the opinion of Ukrainian schoolchildren concerning the desirable President of America among the main candidates to this position D. Trump and H. Clinton. It is stated that this opinion was influenced by mass-media and general sentiments of the population of Ukraine. It is stated that electoral preferences also depend on types of personality. This concerns not only the situation in the country but also situations when electoral judgments concern other countries. The research shows the presence of interest of the schoolchildren in political events in the world if they are widely discussed in mass-media, in the society and if they have general importance for world processes. One of such events were the presidential elections in America. The schoolchildren are aware about the candidates to the President of America and have their own opinion who is better to be the president. Most schoolchildren preferred H. Clinton which corresponded to the general public opinion of the Ukrainian population. Taking into account the structure of values, the supporters of Clinton and Trump among the Ukrainian schoolchildren differ according to their type of personality. The analysis of value priorities of the respondents allows to draw a conclusion that to a greater extent the supporters of Clinton belong to the postmodern type of personality and the supporters of Trump come under the modern type of personality. This conclusion is based on the fact that the supporters of Trump more than the supporters of Clinton value wealth, business, entertainment and the supporters of Clinton more than the supporters of Trump value the possibilities of personal fulfillment, development of their capabilities, creative work.

For the supporters of Trump, it is much more important than for the supporters of Clinton the ambition to create their own business. As it is known, Trump postured himself as a businessman, as a politician who reflected the interests of business. Thus, people who tend to business activities are more inclined to elect Trump. This general trend is also relevant for the Ukrainian schoolchildren. Those among them who see themselves as businessmen in future are more inclined to Trump than to Clinton.

It is stated that electoral preferences depend of types of personality. It is related not only to the situation in one's own country but also to the situations when electoral judgment concern other countries. But such peculiarity of electoral preferences emerges when the subjects of political choice clearly reflect considerable differences in the society. It is strongly possible that if in the Ukrainian political elite political leaders appeared who would clearly reflect the values of modern and postmodern society this would influence to a great extent the electoral preferences of the young voters.

Keywords: presidential elections in America; Ukrainian schoolchildren; interest in politics; electoral preferences; sociological studies; value orientations 


\section{Х. Клинтон или Д. Трамп: выбор американских политиков украинскими школьниками в зависимости от типа личности школьников}

\section{Катаев С. Л., Классический приватный университет}

В статье анализируются материалы социологического исследования, которое состоялось в ноябре 2016, посвященного выявлению мнения украинских школьников относительно желаемого президента Америки среди основных претендентов на эту должность Д. Трампа и Х. Клинтон. Констатируется, что на эти мнения повлияли средства массовой информации и общее настроения населения Украины. Утверждается, что электоральные предпочтения школьников зависят также от их типов личности. Это касается не только ситуаций в своей стране, но и ситуаций, когда электоральные суждения касаются других стран. Исследование показывает наличие у школьников интереса к политическим событиям в мире, если это ширко обсуждается в средствах массовых информации в обществе и имеет общее значение для мировых процессов. Одним из таких событий были выборы президента в Америке. Школьники осведомлены о кандидатах в президенты Америки и имеют свое мнение относительно того, кому лучше быть президентом. Большинство школьников предпочли X. Клинтон, что соответствует общественному мнению украинского населения. Если учитывать тип личности, то сторонники Клинтон или Трампа среди украинских школьников отличаются своими ценностными ориентациями. Анализ ценностных преференций респондентов позволяет сделать вывод, что в большей степени сторонники Клинтон относятся к постмодернистскому типу личности, а сторонники Трампа относятся к типу личности модерного общества. Этот вывод базируется на том, что сторонники Трампа, больше чем сторонники Клинтон, ценят богатство, бизнес, развлечения. А сторонники Клинтон, більше чем сторонники Трампа, ценят возможности самореализации, развитие своих способностей, творческую работу.

Ключевые слова: выборы президента; Соединенные Штаты Америки; украинские подростки; интерес к политике; электоральные предпочтения; социологические исследования; ценностные ориентации

\section{Постановка проблеми.}

$\mathrm{O}$ дним із показників глобалізації є інтерес громадян до міжнародної політики. Особливо це явище притаманне кризовими періодам у міжнародній сфері. Цікавляться міжнародними відносинами не тільки дорослі, а й діти, підлітки. Підлітки поступово опановують дорослий світ і одним із показником цього явища $€$ інтерес до питань, що цікавлять дорослих. Одним із цих питань є світові події. Особливим об'єктом зацікавленості є Америка як найвпливовіша країна світу та союзник України. Вибори президента Америки у листопаді 2016 р. було одним із найважливіших подій світової політики. Результати виборів були цікаві не тільки американцям, а й громадянам інших країн. Зацікавленість результатами виборів і прихильність до одного 3 кандидатів була притаманна не тільки дорослим громадянам України, а і дітям. Підтвердженням цієї думки були результати соціологічного опитування школярів м. Запоріжжя у листопаді 2016 р. напередодні американських виборів.

Мета статті - надати аналіз результатів соціологічного дослідження політичної свідомості школярів і прихильності їх до кандидатів у президенти Америки.

\section{Обговорення проблеми в літературі.}

Інтерес населення до виборчої кампанії вивчається в рамках електоральної соціології. В Україні ця галузь соціологічного знання представлена такими науковцями, як: О. Балакірєва,
I. Бекешкіна, О. Вишняк, С. Головаха, О. Сроменко, I. Кучерів, В. Паніотто, В. Полторак, В. Хмелько, М. Чурилов та ін.

Дослідження політичних поглядів підлітків та ïx відношення до політичних процесів на заході вивчали С. Палонські, Дж. Кевін, Дж. Торні-Пурта [1] та ін .

Ціннісні орієнтації в сфері політики у школярів вивчав російський соціолог В. С. Собкін [2]. Свого часу Н. А. Головін провів дослідження «Діти і вибори», де застосував когортний аналіз «Age-Period-Cohort-Analysis» (APC-Analysis). Він розглядає політичну соціалізацію як процес формування політичних поколінь під впливом масових політико-соціалізуючіх процесів, що відбуваються у визначені історичні періоди: війни, революції, корінні реформи і т.п. [3].

Російські політологи В. Касамара та А. Сорокіна на базі соціологічних досліджень порівнювали політичну свідомість благополучних школярів і безпритульних підлітків [4]. Виявилося, що «найпопулярнішими рисами характеру» ідеального президента «в обох досліджуваних групах стали жорсткість, справедливість, відповідальність, любов до народу, розум і доброта». Дослідники відзначають, що «хлопці, незалежно від свого освітнього рівня (школярі чи діти вулиць), практично позбавлені навички критичного аналізу політичної інформації, одержуваної через 3МI, в школі, від батьків або дорослого оточення» [4]. 
За даними українських дослідників, «73\% дітей вважають, що телевізійна реклама $є$ найважливішим джерелом політичної інформації, 19\% також одержують інформацію 3 преси. Агенти первинної соціалізації, тобто батьки, є джерелом політичної інформації для 18,8\% опитаних молодших юнаків» [5].

Політичну свідомість дітей в Україні досліджували О. А. Безрукова, М. С. Хрустальова та ін. О. Безрукова відмічає: «Процес соціалізації містить у собі громадянсько-політичну складову. На порозі громадянської зрілості в підлітків і юнаків уже $є$ визначені уявлення щодо політики, партій, держави. Ці уявлення формуються під впливом школи, родини, соціального оточення» [5]. Схожі думки висловлювала львівський соціолог Л. Д. Климанська.

\section{Виклад основного матеріалу.}

Питання щодо виборів в Америці було включено до анкети для школярів у дослідженні різних аспектів шкільного життя та свідомості школярів.

Об'єкт дослідження - учні 8-10 класів середніх освітніх закладів (шкіл) м. Запоріжжя. В ході дослідження було опитано 703 учня. Збір даних здійснювався у листопаді 2016 року. Метод збору інформації - анкетування. Вибіркова сукупність була сформована гніздовим методом із випадковим відбором навчальних закладу. При цьому для забезпечення реалізації завдань дослідження при конструюванні вибірки було закладено проведення анкетування у всіх районах м. Запоріжжя.

Статистична похибка вимірювання: максимальне відхилення результатів, отриманих за допомогою вибіркового анкетування від даних генеральної сукупності, становить $3,1 \%$.

Таблиия 1.

Характеристики вибіркової сукупності

\begin{tabular}{|l|l|l}
\hline \multirow{4}{*}{ вік } & 13 років & $22,7 \%$ \\
\cline { 2 - 3 } & 14 років & $32,4 \%$ \\
\cline { 2 - 3 } & 15 років & $30,2 \%$ \\
\cline { 2 - 3 } & 16 років & $11,0 \%$ \\
\hline \multirow{2}{*}{ стать } & Чоловік & $42,3 \%$ \\
\hline \multirow{4}{*}{ клас навчання } & Жінка & $57,7 \%$ \\
\hline & Восьмий & $35,7 \%$ \\
\hline & Дев'ятий & $33,4 \%$ \\
\hline & Десятий & $30,8 \%$ \\
\hline
\end{tabular}

Про рівень інтересу школярів до політики свідчать відповіді на запитання: «Чи цікавитеся
Ви політикою?». Результати опитування наведені в таблиці 2.

Таблиия 2.

Відповіді на запитання: «Чи цікавитеся Ви політикою?»

\begin{tabular}{|l|l|}
\hline Зовсім не цікавлюся. & $37,2 \%$ \\
\hline В якійсь мірі цікавлюся & $51,0 \%$ \\
\hline Намагаюся постійно бути в курсі політичних подій. & $10,4 \%$ \\
\hline Беру активну участь у політичному житті. & $1,4 \%$ \\
\hline
\end{tabular}

Як бачимо з таблиці, майже дві третини школярів у тій або іншій мірі цікавляться політикою. Це учні переважно старших класів. Ці дані спростовують поширену думку, що діти зовсім не цікавляться політикою. Вони не артикулюють чітко свої прихильності у політиці, їх інтерес скоріше має характер загальної зацікавленості різними аспектами дорослого життя. Інтерес до політики у дітей також стимулюється телевізійними пере- дачами, які часто діти переглядають разом із батьками.

О. Безрукова відмічає: «Як показують дослідження, підлітки та молодше юнацтво насправді обізнані у політичній ситуації, розкладі політичних сил, статусі політичних та громадянських інституцій. Але вони не мають нагоди проявити своє знання та свої інтереси. Вони ще не включені в ситуації політичного вибору, тому свої політич- 
ні смаки вони залишають при собі. Громадянські цінності не $є$ актуальними постійно, їх не активізують щодня, вони існують у схованому стані, наче відкладені для використання в екстремальних випадках» [5].

Інтерес дітей до виборів президента Америки певним чином обумовлений зацікавленістю громадян України станом влади в Америці. Дорослі мешканці України мають свою думку щодо якостей президента Америки. Так, на питання «Яку оцінку Ви б дали діяльності Б. Клінтона / Дж. Буша / Б.Обами на посаді Президента США, якщо «1»найнижча, а «10» - найвища оцінка?» середній бал оцінки Б. Клінтона - 7,6, Дж. Буша - 5,3, Б. Обами - 5,9. Це досить високі оцінки, адже середня оцінка президента України у 2016 році - 3,0 [ 6, с. 435 ].

Вибори в Америці були своєрідним хітом політичних програм і діти частіше за все реагували на них, як реагують на будь який хіт у інформаційному просторі. Бути «в курсі» найважливіших політичних подій відповідає бажанням підлітків бути сучасними та причетними до суспільного життя. Інтерес до політики є частиною загальної соціалізованості школярів.

Стосовно виборів в Америці було задано наступне запитання: «Будучи громадянином США, за кого Ви б проголосували?». Результати опитування наведені в таблиці 3.

Таблиця 3.

Відповіді на запитання: «Будь Ви громадянином США, за кого Ви б проголосували?»

\begin{tabular}{|l|l|}
\hline Дональд Трамп & $24,9 \%$ \\
\hline Хілларі Клінтон & $40,2 \%$ \\
\hline Важко відповісти & $34,9 \%$ \\
\hline
\end{tabular}

Як бачимо з таблиці, українські школярі надавали перевагу Хілларі Клінтон. Відомо, що хоча Д. Трамп одержав перемогу на виборах, абсолютна більшість громадян Америки обрала Х. Клінтон. Лише особливості формату виборів президента в Америці дозволили одержати перемогу кандидату, який отримав менше голосів, ніж суперник. Отже, українські школярі в цілому за своїм вибором майбутнього президента тотожні американським громадянам. На вибір школярів також вплинули думки дорослих та загальний пріоритет Х. Клінтон у телевізійних програмах в Україні. Як відомо, український політикум був більше схильний до Х. Клінтон, ніж до Д. Трампа. В цьому питанні думка українських школярів цілком співпадає з думкою дорослих. Так, Радіо Свобода відзначало, що «представники української влади часто висловлювали прихильність на користь кандидата Хілларі Клінтон під час виборів [7].

Можна погодитись 3 О. Безруковою, що «діти не мають самостійного політичного статусу і не займають самостійних позицій у громадянсько-політичному середовищі. Вони частково привласнюють політичну власність своїх батьків, своєї соціальної або етнічної спільноти. Це пояснює той факт, що за партійно-політичними уподобаннями діти співпадають з дорослими» [5].

Хоча в цілому пріоритет у виборах майбутнього президента в Америці в очах українських школярів залишався за Х. Клінтон, певний відсоток підлітків надав перевагу Д. Трампу. Причину відмінності у думках школярів стосовно прихильності до майбутнього президента Америки ми вбачаємо у соціокультурних характеристиках підлітків. Ми порівняли деякі ціннісні пріоритети школярів зі схильністю до вибору кандидатури президента. У відповідній анкеті містилося питання про ціннісні орієнтації респондентів. Результати порівняльного аналізу наступні. Для прихильників Трампа цінність вищої освіти вища, ніж для прихильників Клінтон ( відповідно 66\% і 61\%). Тож, у певній мірі, рівень досягальних цінностей у прихильників Трампа вищий, ніж у прихильників Клінтон. Тобто прихильники Трампа більш динамічні, більше приділяють увагу знанням та освіченості. Дуже показово також, що для прихильників Трампа значно важливіше, ніж для прихильників Клінтон, прагнення створення власного бізнесу (відповідно 29,0\% - 19\%). Як відомо, Трамп позиціонувався як бізнесмен, як політик, що відображає інтереси бізнесу. Тож люди, що прагнуть до бізнесової діяльності, у більшій мірі схильні обирати Трампа. Ця загальна тенденція притаманна $\mathrm{i}$ для українських школярів. Ті з них, хто у майбутньому бачить себе у якості бізнесмена, більше схильні до Трампа, ніж до Клінтон.

Прихильники Трампа серед школярів проявляють більший динамізм у своїй життєдіяльності, про що свідчить значно більша значущість для них, ніж для прихильників Клінтон, такої цінності як «Задоволення та розваги» (відповідно 30\% та 19\%). Ця думка підтверджується також тим фактом, що цін- 
ність «Накопичення багатства та високі доходи» більш значуща для прихильників Трампа, ніж для прихильників Клінтон (відповідно $29 \%$ та 24\%).

Тип особистості прихильників Трампа більш схожий на модерний. Вони більш схильні у майбутньому займатись бізнесом та розважатись. Ці риси способу життя притаманні для бажаного образу майбутнього для підлітків модерного суспільства споживання.

Тип особистості прихильників Клінтон більш схожий на постмодерний. Так, для прихильників Клінтон така постмодерна цінність як «розвиток своїх здібностей, самореалізація» значно важливіша, ніж для прихильників Трампа (відповідно 68\% і 55\%). На приналежність даної цінності до постмодерного типу особистості зазначають багато вчених. Зокрема, ця думка висловлюється в роботах Л. Сокурянської, присвячених дослідженню ціннісних орієнтацій молоді, з яких, до речі, був запозичений перелік цінностей у нашій роботі [8].

Відповідає логіці постмодерної особистості також обрання цінності «цікава, творча робота». Цю цінність частіше обирали прихильники Х. Клінтон (відповідно 51.0\% 45\%). Постмодерній особистості притаманна більша схильність до творчості, а не до багатства, матеріальних цінностей. Як відомо, за Х. Клінтон голосувала Кремнієва долина, креативний клас, мешканці найбільш розвинутих штатів Америки.

В цьому випадку, як і в інших, ми завертаємо увагу на тенденції, відносні переваги у цінностях прихильників різних кандидатів. Загалом, обом групам школярів притаманні загальні риси сучасної молоді. I такі цінності, як самореалізація, творча робота, вища освіта для обох груп респондентів займають високі рейтинги. Але певні розбіжності у значущості цих цінностей вказують на відносну різницю у типах особистості, що і відображають результати дослідження. Це міркування стосується і відношення до такої цінності, як «особиста свобода, незалежність у судженнях та діях». Ця цінність значуща для всіх сучасних школярів, але для постмодерних прихильників Х. Клінтон дана цінність дещо важливіша (відповідно 51\% та 48\%).

Для постмодерного суспільства у певній мірі важливіші духовні цінності. Це, зокрема, вплинуло на деякий зсув у відношенні до релігії. Для модерного типу особистості більш притаманний секулярізм, байдужість до релігії. У постмодерному суспільстві повертається інтерес до релігії, але у інших формах, ніж у традиційному суспільстві. Ці відмінності у певній мірі відображаються і у відношеннях до релігії школярів, що належать до різних типів особистості. Так, цінність «життя згідно 3 релігійними заповідями» частіше обирається прихильниками Х. Клінтон (відповідно $26 \%$ та $23 \%$ ), а пункт «не знаю» частіше обирається прихильниками Трампа (відповідно $14 \%$ та10\%).

Переваги деяких цінностей можуть бути пояснені не обов'язково різницями у типах особистості за критерієм «модерний - постмодерний». Прикладом може слугувати різниця у відношенні до такої цінності, як «допомога іншим людям». Прихильники Трампа обирали цю цінність частіше за прихильників Клінтон (відповідно 39\% та 33\%). Другим прикладом слугує різниця значущості цінності «наявність надійних друзів». Цю цінність частіше обирали прихильники Х. Клінтон (відповідно $75 \%-68 \%$ ).

Отже, електоральні переваги залежать від типів особистості. Це стосується не тільки ситуацій у своїй країні, а і ситуацій, коли електоральні судження стосуються інших країн. Але така особливість електоральних переваг виникає тоді, коли об'єкти політичного вибору чітко віддзеркалюють значні відмінності у суспільстві.

\section{Висновки.}

Дослідження показує наявність у школярів інтересу до політичних подій у світі, якщо це ширко обговорюється у засобах масових інформації, у суспільстві та має загальне значення для світових процесів. Однією 3 таких подій були вибори президента в Америці. Школярі обізнані про кандидатів в президенти Америки та мають свою думку щодо того, кому краще бути президентом. Більшість школярів надали перевагу Х. Клінтон, що відповідає загальній суспільній думці українського населення. Якщо зважати на структуру цінностей, то прихильники Клінтон та Трампа відрізняються за своїм типом особистості. Аналіз ціннісних преференцій респондентів дозволяє зробити висновок, що у більшій мірі прихильники Клінтон належать до постмодерного типу особистості, а прихильники Трампа відносяться до модерного типу особистості. 
Цей висновок базується на тому, що прихильники Трампа, більше ніж прихильники Клінтон, цінують багатство, бізнес, розваги, а прихильники Клінтон, більше ніж прихильники Трампа, цінують можливості самореалізації, розвиток своїх здібностей, творчу роботу.

Стверджується, що електоральні переваги школярів залежать від типу особистості. Це стосується не тільки ситуацій у своїй країні, а і ситуацій, коли електоральні судження стосу- ються інших країн. Але така особливість електоральних переваг виникає тоді, коли об'єкти політичного вибору чітко віддзеркалюють значні відмінності у суспільстві. Цілком ймовірно, що якби і в українському політикумі з'явились політичні лідери, які чітко віддзеркалювали би цінності модерного або постмодерного суспільства, то це значною мірою вплинуло би на електоральні переваги молодих виборців.

\section{БІБІЛІОГРАФІЧНІ ПОСИЛАННЯ}

1. Torney-Purta J. Adolescents' Political Socialization in Changing Contexts: An International Study in the Spirit of Nevitt Sanford / J. Torney-Purta // Political Psychology. Special Issue (Part Two): Prospect Theory. - 2004. - Vol. 25.

2. Собкин В. С. Различие ценностных ориентации в сфере политики у разных поколений старшеклассников / В. С. Собкин // Социология образования. Труды по социологии образования. Т. ХIII. Вып. XXII. - М.: Институт социологии образования РАО, 2009.

3. Головин Н. А. Дети и выборы в Государственную Думу: о формировании базовых политических установок / Н. А. Головин, В. А. Сибирев // Журнал социологии и социальной антропологии. - 2001. - № 4. - С. $116-134$.

4. Касамара В. Политическое сознание подростков: благополучные школьники vs дети улиц / В. Касамара, А. Сорокина // Полис. Политические исследования. - 2009. - № 6. - С. 68-82.

5. Безрукова О. А Громадянське-політична соціалізація юнацтва регіону (на прикладі м. Запоріжжя): автореф. дис. на здобуття наук. ступеня канд. соціол. наук. - Запоріжжя, 2006. -24 с.

6. Українське суспільство: моніторинг соціальних змін. Випуск 3 (17) / за ред..: В. М.Ворони, М. О. Шульги. Київ: Інститут соціології НАН України, 2016. - 550 с.

7. Україні треба готуватись до розслідування щодо втручання у вибори США - політолог. - Режим доступу: https://www.radiosvoboda.org/a/28637772.html

8. Сокурянская Л. Г. Ценностные ориентации подростковой молодежи пограничья Центральной и Восточной Европы (по результатам международного исследования) / Л. Г. Сокурянская // Методологія, теорія та практика соціологічного аналізу сучасного суспільства. Збірник наукових праць. - Вип 21. - Харків: Вид центр ХНУ ім. В. Н. Каразіна. - 2015. - С. 251-258.

\section{REFERENCES}

1. Torney-Purta J. (2004) Adolescents' Political Socialization in Changing Contexts: An International Study in the Spirit of Nevitt Sanford. Political Psychology, 25 (3). Special Issue (Part Two): Prospect Theory.

2. Sobkin, V.S. (2009) Razlichie tsennostnych orientatsiy v sfere politiki u raznych pokoleniy starsheklasnikiv [The difference in value orientations in the sphere of politics in different generations of senior pupils]. Sociology of Education. Works on the Sociology of Education. T. XIII. Issue. XXII (Edited by VS Sobkin)]. Moscow: Institute of Sociology of Education RAO [in Russian].

3. Golovin, N.A., \& Sibirev, V.A. (2001) Deti i vybory v Gosudarstvennuiu dumu: o formirovanii bazobych politicheskih ustanovok [Children and elections to the State Duma: the formation of basic political guidelines]. Zhurnal sotsiologii $i$ sotsialnoy antropologii, 4, 116-134 [in Russian].

4. Kasamara, A., \& Sorokina, A. (2009) Politicheskoe soznanie podrostkov: blagopoluchnye shkolniki vs deti ulits [Political consciousness of adolescents: well-off schoolchildren vs street children]. Polis. Politicheskie issledovaniya, 6 , 68-82 [in Russian].

5. Bezrukova, O.A. (2006). Gromadianske-politichna sotsializatsiya yunatstva regeonu na prikladi Zaporizhzhya [Civicpolitical socialization of the youth of the region (on the application of Zaporizhzhya)]. Extended abstract of candidate's thesis. Zaporozhye [in Ukrainian]

6. Vorona, V.M., \& Shulga, M.O. (Eds.). (2016) Ukrainske suspilstvo: monitoring sotsialnych zmin [Ukrainian society: monitoring social change]. Issue 3 (17). Kyiv: Institute of Sociology of the National Academy of Sciences of Ukraine [in Ukrainian].

7. Ukraini treba gotuvatys do rozsliduvanny schodo vtruchanny u vybory SShA-politolog [Ukraine needs to prepare for an investigation into interference in the US elections - a political scientist]. Retrieved from: https://www.radiosvoboda. org/a/28637772.html [in Ukrainian] 
8.Sokurianskaya, L.G. (2015) Tsenostnye orienatsii podrostkovoy molodezhi pogranishya Tsentralnoy I Vostochnoy Evropy ( po rezultatram mezhdunarodnogo issledovaniy) [Value orientations of adolescent youth of the borderland of Central and Eastern Europe (according to the results of international research) ]. Metodologiy, teoriy ta praktika sotsiologichnogo anflizu sushasnogo suspilstva. Vol. 21. (pp. 251-258). Kharkiv: View the center of the KNU them. V. N. Karazin [in Russian].

\section{Катасв Станіслав Львович}

Доктор соціологічних наук, професор, зав. каф. соціології і соціальної роботи

Класичний приватний університет

69000, Запоріжжя, вулиця Жуковського, 70Б

\section{Kataev Stanislav}

Doctor of Sociological Sciences, Professor, Head of the Department of Sociology and Social Work Classical private university

70B, Zhukovsky St., 69000, Zaporizhzhya, Ukraine

ORCID: 0000-0003-3140-6540 Email:kataev@i.ua

Цитування: Катаєв С. Л. Х. Клінтон або Д. Трамп: вибір американських політиків українськими школярами в залежності від типу особистості школярів / С. Л. Катаєв // Науково-теоретичний альманах «Грані». - 2018. - Т. 21. - № 5. - С. 13-19

Citation: Kataiev, S.L. (2018). Kh. Klinton abo D. Tramp: vybir amerykanskykh politykiv ukrainskymy shkoliaramy v zalezhnosti vid typu osobystosti shkoliariv [H. Clinton or D. Trump: the Choice of American Politicians by the Ukrainian Schoolchildren Depending on the Schoolchildren's Type of Personality ]. Scientific and theoretical almanac «Grani», 21(5), 13-19 